TEME, г. XLIV, бр. 2, април - јун 2020, стр. 549-564

Оригинални научни рад $\quad$ https://doi.org/10.22190/TEME181005039S

Примљено: 5. 10. 2018.

UDK $338.48+640.4$

Ревидирана верзија: 18. 3. 2019.

Одобрено за штампу: 15. 4. 2020.

\title{
COMPETENCY MODEL AND MULTI-CRITERIA DECISION MAKING IN TOURISM AND HOTEL INDUSTRY IN SERBIA
}

\author{
Nataša Stanišić, Slobodan Čerović* \\ Singidunum University, Faculty of Tourism and Hospitality Management, \\ Belgrade, Serbia \\ *scerovic@singidunum.ac.rs
}

\begin{abstract}
In today's global and highly competitive business world what essentially differentiates one organization from another are the people who work there. Regardless of the technological advantages of a hotel or a travel agency, the people, their development, motivation and satisfaction are key factors for success on the market. Therefore, many hotels started applying competency models to determine skills, knowledge and personal characteristics needed for good business performance. The advantages of this model are also reflected in the recruitment, selection, training, development, promotion, performance evaluation, and rewarding employees. The emphasis is on the selection of career advancement criteria by the multi-criteria decision-making process, the essence of which is to identify all available criteria for comparing possible alternatives, to compare all the alternatives according to the selected criteria, and thus to choose the most favourable alternative. The aim of the research is to develop a software package that will, based on executive manager's selection in a hotel and a travel agency, present specific steps of business decision-making application in the field of human resources. The AHP method is used to conduct a weight analysis of professional competencies prioritized for future reference in terms of career advancement. Sampling methods for data collection from eight top hotel managers and five travel agency managers are used for the purpose of this paper, as well as qualitative and quantitative surveys including interviews and questionnaire. A detailed case study illustrates the application of the proposed evaluation system for management staff advancement in tourism and hotel industry. The estimated results show that the most important criterion is professional knowledge, followed by business planning and subsequently team work and foreign language skills.

This solution is general and can also be applied in candidates ranking for employment, promotion or training.
\end{abstract}

Key words: human resource management, competency, decision - making, tourism, hotel industry. 


\title{
МОДЕЛ КОМПЕТЕНЦИЈА И ВИШЕКРИТЕРИЈУМСКО ОДЛУЧИВАЊЕ У ТУРИЗМУ И ХОТЕЛИЈЕРСТВУ СРБИЈЕ
}

\begin{abstract}
Апстракт
У савременом глобалном и изузетно конкурентном пословном свету, оно што суштински разликује једну организацију од друге јесу људи који у њој раде. Без обзира на технолошке предности које неки хотел или туристичка агенција може имати, људи, њихов развој, мотивација и задовољство кључни су за успех на тржишту. Стога, многа хотелска предузећа почела су да примењују моделе компетенција како би одредили вештине, знања и личне карактеристике потребне за добар пословни учинак. Предности овог модела огледају се и у процесима регрутације, селекције, обуке, развоја, напредовања, процене радне успешности, награђивања запослених. Акценат је стављен на избор критеријума за напредовање запослених помоћу вишекритеријумског одлучивања, чија је суштина да се уоче сви могући критеријуми за поређење могућих алтернатива, да се све алтернативе упореде по изборима релевантних критеријума и тако изабере најповољнија. Циљ истраживања је осмислити софтверски пакет који ће на примеру избора извршних менаџера у хотелу и туристичкој агенцији приказати конкретно све кораке примене пословног одлучивања у области људских ресурса. У раду је коришћен АНР метод у циљу анализе тежинских коефицијената стручних компетенција приоритетних за будуће напредовање у каријери. За потребе ове студије коришћене су методе узорковања за прикупљање података од стране осам топ-менаџера хотела и пет менаџера туристичких агенција и квалитативна и квантитативна истраживања, укључујући интервјуе и анкете. Приказана је детаљна студија случаја, која илуструје примену предложеног система оцењивања при одређивању критеријума за напредовање у туризму и хотелској индустрији. Добијени резултати показали су да је професионално знање најважнији критеријум, затим пословно планирање, а потом тимски рад и знање страних језика.

Ово решење је опште и може се применити и на рангирање кандидата при запошљавању, напредовању, усавршавању.
\end{abstract}

Кључне речи: менаџмент људских ресурса, компетенције, доношење одлука, туризам, хотелска индустрија.

\section{INTRODUCTION}

This paper used multi-criteria decision and the AHP method. The analytic Hierarchy Process (AHP) approach is fast and suggests ranking as a guideline in the final ranking. It is a multi-criteria decision-making approach introduced by Saaty (Saaty, 1980a). The AHP has attracted the interest of many researchers mainly due to nice mathematical properties of the method and the fact that the required input data are rather easy to obtain. The AHP is a decision support tool, which can be used to solve complex decision problems. It uses a multi-level hierarchical structure of objectives, criteria, sub-criteria, and alternatives. The advantage of this technique compared to similar multi-criteria decision making techniques is speed. Although the obtained solution is approximate, it is good enough to be used for defining career advancement criteria. 
The scope of our research is defining key managerial competencies using multi-criteria decision making in solving the problem of management staff promotion. The model defined here can be easily applied to selection, promotion, performance evaluation, and similar issues. The remainder of the paper is organized as follows: the first part defines the basic terms of competency models and multi-criteria decision making. This is followed by a survey of related works in the field of competency models and general multi-criteria decision making. The third part provides the description of paper methodology and the review of tools necessary for the implementation of the AHP method. The central part of the paper is dedicated to developing a weight professional competency framework for managers in tourism and hotel industry in Serbia. The paper concludes with final findings and discussion.

\section{LITERATURE REVIEW}

\section{Defining Competency}

Competency could be defined as the ability to successfully perform a specific task or a job. More specifically, it is the ability of a person to demonstrate that they can perform certain tasks or activities according to the required standards. It could also be said that the competencies are the overall prerequisites for performance (Šiber, 1999a, p. 346).

Today, many companies define the general (key) competencies that can be applied to all workplaces and specific competencies that apply only to specific jobs.

Table 1 shows the structure of general management competencies that contains four main categories of competencies - intellectual, interpersonal, adaptability, and result orientation.

Table 1. General Management Competencies

(Šiber, 1999b, p. 347)

\begin{tabular}{ll}
\hline General competencies & Individual competencies \\
\hline Intellectual & Strategic perspective / Analysis and assessment \\
& Planning and organizing \\
\hline Interpersonal & Staff management / Persuasiveness \\
& Assertiveness and decisiveness / Interpersonal sensitivity \\
& / Oral communication \\
\hline Adaptability & Adaptability and mobility / Flexibility \\
\hline Result orientation & Energy and initiative / Achievement motivation \\
& Business acumen \\
\hline
\end{tabular}

A more detailed analysis of the existing competency classification shows that they combine various complex activities (for example, staff management) with specific individual abilities and personality traits (persuasiveness, decisiveness, initiative, etc.) (Šiber, 1999c, p. 347). 


\section{Competency Models}

David McClelland (1973) was the first to propose competencies as a critical differentiator of performance in the early 70's (Boyatzis, 2008a). $\mathrm{He}$ argued that traditional achievement and intelligent tests cannot be used to predict performance. It is necessary to profile competencies required to perform a job effectively (Chouhan \& Srivastava, 2014).

The first model was developed by Boyatzis, who conducted his research at the time when the organization expressed a need for distinguishing high- from low- performing managers and rewarding the right people (Wood \& Payne, 1998). Boyatzis defined competency as the underlying characteristic that could be a motive, trait and aspect of selfimage or social role.

According to a research conducted over the last 30 years in the paper "Competencies for the 21 century", Boyatzis suggested 3 clusters of competencies required for successful job performance at key positions within organizations: expertise and experience, knowledge and the assortment of basic cognitive competencies (Boyatzis, 2008b).

Spencer and Spencer, who furthered on Boyatzis work, emphasized that competencies must be related to performance in the workplace (Spencer \& Spencer, 1993).

Robertson, Callinan and Bartram presented a contemporary competency model in 2002 in which they distinguished four sets of variables essential for successful job performance - competency potential, competencies, context, and outcome results (Kurtz \& Bartram, 2002a).

Bartram and associates in their model adopt a three-tier structure of competency - 110 competency components, 20 competencies, and eight competency factors on the top tier. Competency components are elemental, serving as building blocks for sets of competencies, and they can be applied for detailed profiling of different job layers within an organization. This analysis covers managerial and non-managerial positions (Kurtz \& Bartram, 2002b).

In the broader sense, competencies are considered to be dimensions of those competencies that encompass the competencies frequently identified in job analysis over the period of the last twenty years and used for assessment and development centres (Kurtz \& Bartram, 2002c).

\section{Advantages of the Competency Model}

Many companies in the world started to use competency models in order to employ people with great potential in an easier and faster way, to provide employee training and development, and to enable the evaluation system that would provide the employees with the necessary feedback (information on working performance) and training that would help them successfully perform their tasks. Although a precise definition of competency 
is non-existent, each company, depending on the type of work and market requirements, identifies key skills, knowledge and personal traits necessary for successful job performance. Human resources sector can largely benefit from the competency approach, in terms of job analysis and design, human resources planning, selection and the recruitment of candidates, training and development of employees, and performance assessment. At the organizational level, the assessment of relevant individual and common behaviours may enable the identification of the presence or absence of the key competencies. For example, a company can determine whether its employee selection and training system is successful in terms of the employees' development with a set of appropriate skills, knowledge and characteristics required for long-term successful business operations.

Regardless of the problem the company is facing, whether it is a cultural change due to a takeover by another company, or a merger of two companies, a change in the business strategy, or the need to respond to market competition, the solutions begin and end with the company employees. It is the workforce that needs to adapt to changes, to adjust the behaviour to the new business priorities, or to be ready to meet the challenges of tomorrow (Horney \& Koonce, 1995).

The advantage of the competency approach is that it offers a method for identifying the skills that people must possess to meet business challenges and guide human resources management towards the appropriate forms of behaviour that is key to the success of the company.

\section{Competency Model in Tourism and Hotel Industry in Serbia}

The dynamism that characterizes the tourism sector leads to the need for employee flexibility (Juul, 2015; RPA, 2012). Their importance is reflected in the fact that employees are the key factor in the service delivery process. The prerequisites are aimed at performing different tasks and functions necessitating multifunctional and multidisciplinary worker knowledge and skills that can fit into a shifting and challenging work environment (Stefanović, Blagojević, 2009a).

Hotels that are part of large hotel chains have defined profiles based on job description for each work position. When considering the particularities of a hotel or a country in which it operates, the competency model could provide a more complex framework for the employees' requirements and thus ensure that performing certain tasks would not lead to oversights or the neglect of the specifics important for meeting the set goals.

The competency model could help hotels and travel agencies determine the criteria for career advancement, and thus select potentially best performing workers. The application of this model provides necessary feedback, i.e. provides timely information on whether the employee possesses the required qualifications and characteristics to their direct 
superiors. In addition to revealing the fact which candidates have the potential for advancement, the said model also provides a detailed account of the advancement of other potential candidates.

With respect to tourism and hotel industry in Serbia, and especially in Belgrade, all chained-brand hotels in the world elaborated competency models they use for selection, recruitment, training, development and the evaluation of the employees' performance. All data relating to employee promotion were not available to the public due to privacy policies. Smaller hotels performed a job analysis, whereas the exact job specification was nonexistent at the time ${ }^{1}$.

The competency approach within the travel agencies was applied in larger agencies that were present on the market for many years.

Apart from clearly defining employee advancement criteria and depending on individual dispositions and environment, i.e. business culture of the country they operate in, the proposed competency model would enable HR managers to assign weight to criteria thus adjusting them to the business and market's demands. On the other hand, it would provide variety in tourism offer. Therefore, the competency model needs to be revised and innovated in accordance with the demands of the Serbian tourism market. The introduction of the competency model would enable the implementation of the organization's value and the harmonization of the personal dispositions with the job specifications.

This paper uses the competency model presented in Table 1 (necessary knowledge in tourism) (Stefanović \& Blagojević, 2009b, p. 505), based on which four criteria were selected and applied in the case study.

\section{Multi-criteria Decision Making and AHP Method}

$M C D M$ is considered to be a suitable methodology when it comes to decision-making process or solving problems that consist of several elements considered. All possible criteria for comparing possible alternatives are identified, by choosing the relevant criteria all alternatives can be compared, and thus the most favourable alternative is selected. The paper uses Analytic Hierarchy Process (AHP). It is a multi-criteria decisionmaking approach introduced by Saaty (Saaty, 1980b) that uses a multi-level hierarchical structure of objectives, criteria, sub-criteria, and alternatives.

The relevant AHP data are obtained by using two-criterion comparison sets (pairwise comparisons). These comparisons are used to compute the weight and relative performance of all alternatives with respect to each individual decision-making criterion. If the comparisons are not perfectly consistent, the AHP method provides a mechanism for

\footnotetext{
${ }^{1}$ Data obtained in conversations with HR managers of Hyatt Regency, Crowne Plaza,
} Holiday Inn, Excelsior Hotel in Belgrade, and Hotel Palisad on Mt. Zlatibor 
improving consistency. The approach proposed by Saaty in the work quoted is pairwise comparison used to determine the relative importance of each alternative in terms of each criterion. According to this approach, the decision maker must express their opinion of the value of the pairwise comparison at a given time. Since pairwise comparison is key to the decision-making process, proper quantification is the most important step in the multi-criteria decision-making method that uses qualitative data (Stanković, 2013).

Table 2. Saaty's pairwise comparison with nine grades

\begin{tabular}{ll}
\hline Value of & Interpretation \\
$\mathrm{a}_{\mathrm{ik}}$ & Comparison factors $\mathrm{j}$ and $k$ \\
\hline 1 & $\mathrm{j}$ and $\mathrm{k}$ are equally important \\
3 & $\mathrm{j}$ is slightly more important than $\mathrm{k}$ \\
5 & $\mathrm{j}$ is more important than $\mathrm{k}$ \\
7 & $\mathrm{j}$ is strongly more important than $\mathrm{k}$ \\
9 & $\mathrm{j}$ is absolutely more important than $\mathrm{k}$ \\
$2,4,6,8$ & Intermediate values between adjacent scales \\
\hline
\end{tabular}

Pairwise comparisons are quantified by using a scale. The scale initially proposed by Saaty is given in Table 2 . In the next chapter, we will give a detailed overview of the description of the criteria that we applied. We will describe the way in which we apply the AHP method to determine the weight of the criteria, starting from defining the hierarchy of grades and the corresponding assessment matrix. In conclusion, the concrete results will be provided, namely the corresponding weight factors.

\section{RESEARCH METHOD}

\section{Case Study - Advancement of Management Staff in Tourism and Hotel Industry}

The demand for flexibility and mobility of employees is strongly expressed in tourism. Flexibility demand is visible in the imperative that the employees must possess more than one skill, either combined with different qualifications, or in combination with the specific skills that are generally related to different qualifications. This results in development and the emergence of new hybrid forms of occupation where one employee is doing several jobs that require special training and specific occupations (Stefanović \& Blagojević, 2009c, p.506). 
Table 3. Necessary knowledge/skills in tourism (Stefanović \& Blagojević, 2009d, p.506)

\begin{tabular}{llll}
\hline $\begin{array}{l}\text { Knowledge and } \\
\text { competencies }\end{array}$ & Managers & Expert associates & All employees \\
\hline - Planning and & - Computer skills & - Expert & - Professional \\
organizing & - Business & competencies & competencies \\
- Focus on & planning & - Problem solving & - Technical skills \\
customers & - Managerial & - Basic computer & - On-the-job \\
- Communication & skills & skills & training \\
- Foreign language & - Change & - Knowledge & - Personal \\
skills & management & innovation & development \\
- Understanding & - Performance & - Project and work & - Occupational \\
between the & management & process & safety and \\
cultures & - Decision & management & protection \\
- Teamwork & making & - Communication & - Customer-and- \\
- Flexibility & - Human & - Specialized & result-focused \\
- Problem solving & potential & competencies & \\
- Training skills & management & - Presentation skills & \\
- HR management & - Destination & - Creativity and & \\
& management & innovation & \\
& - Project & & \\
& - Education for & & \\
\hline
\end{tabular}

\section{Data Collecting Procedures}

This paper uses qualitative and quantitative methods. The first stage includes interviews with hotel experts as to obtain information and identify key managerial competencies. For the purpose of the paper, top managers are defined as having a formal hierarchical position, work experience and expert knowledge. Since all data relating to employee promotion were not available to the public due to privacy policies, based on literature review and interviews with top managers we tried to clarify key competencies for employee promotion. Further, the AHP method was used to establish a weight competency framework in the hotel industry. We used this method due to its ability to verify the consistency of decisions made by a decision maker and the fact that the required input data were rather easy to obtain. This method turned the complex decision-making process into simple comparisons. Although the obtained solution was approximate, it was good enough to be used for the defining of the career advancement criteria. The research was made on a sample consisting of eight 4- and 5-stars hotels and five travel agencies. Based on literature review and interviews results, four criteria for advancement of managers were defined. Of the ten criteria, four were selected depending on what decisions should be made, for example, whether it was a payment of fees, promotion, training, or recruitment. For the purposes of this case study, four criteria were selected from the above table. 


\section{Criteria:}

C1. Foreign language skills

C2. Professional knowledge

C3. Business planning

C4. Teamwork

\section{Employee evaluation}

In the second stage, we interviewed 13 top managers and used the AHP to conduct a weight analysis of professional competencies prioritized for future reference in terms of career advancement. Employees were evaluated based on the necessary skills and knowledge defined for each of the above criteria.

For the first criterion, it was assessed whether knowledge of a foreign language was required for the workplace, and then the obtained certificates were taken into account according to the pre-determined table.

Table 4. Grades for the first criterion (level)

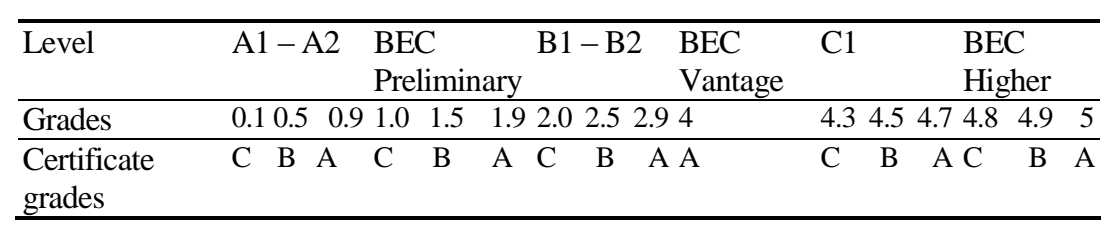

Table 5. Grades for the second criterion (certificates)

\begin{tabular}{lcc}
\hline Certificate & British Council & Licensed foreign language schools \\
\hline Grades & A (5), B (4,5), C (4) & F - C $(1-4)$
\end{tabular}

Level BEC Vantage with grade 4.0 was observed. After that, the grade a candidate achieved for appropriate certificate was taken into account.

For the second criterion - professional knowledge, the diploma of completed studies, diploma supplements, professional development, etc. were taken into account. Grades were defined according to pre-defined tables.

\section{Model Table}

Table 6. Grades for the second criterion

\begin{tabular}{|c|c|}
\hline Loc & $\overline{F o}$ \\
\hline iverage during studies) & grade average during \\
\hline
\end{tabular}

Grades from 6 to 10 were scaled to grades 1 through 5 .

Diploma supplement - internationally recognized certificates 
Additional training - studies abroad, seminars, conferences

Diploma supplements and additional training added value from the grade average to grade five.

For the third criterion, business planning, the history of business planning was monitored, how the plans were realized, and their success rate, according to the pre-defined criteria.

Table 7. Grades for the third criterion

\begin{tabular}{lccccc}
\hline & $75-80 \%$ & $81-85 \%$ & $86-90 \%$ & $91-95 \%$ & $96-100 \%$ \\
\hline Success rate & 1 & 2 & 3 & 4 & 5 \\
\hline
\end{tabular}

For the fourth criterion, teamwork, candidates evaluated other candidates with scores from 1 to 5 using surveys (the case study developed in this paper used GoogleDocs).

\section{IMPLEMENTATION}

Determining grades

The management of a hotel/travel agency evaluated five employees for the purpose of advancement. Evaluation was made according to the four pre-defined criteria.

\section{The first criterion (foreign language skills)}

The holder of the British Council certificate, grade A, level BEC Vantage. The table shows that the grade A for the level BEC Vantage is 4.0.

\section{The second criterion (professional knowledge)}

The candidate graduated from the University of Florida, USA (Bachelor of Science degree in Tourism, Tourism and Hospitality Management), which is in the top 10 schools in the USA, with average grade 8.4 (4.2). Candidate had a USA diploma supplement for computer skills, and one year of additional training in Great Britain. Diploma supplement weighs 0.2 , additional training additional 0.3 , so the average grade was increased from 4.2 to 4.7 .

\section{The third criterion (business planning)}

The candidate success rate for the previous period was $67 \%$, so the grade was 3.0. 


\section{The fourth criterion (teamwork)}

\section{Survey \\ Team building}

This stage of our research included interviewing 8 hotel and 5 travel agencies experts with the aim of identifying important factors for team building. Each of them was interviewed and asked to fill out an open-ended questionnaire about their perceptions of the teamwork measures. Their answers were compared and key descriptions for team building were identified. They were offered the following options:

1. Initiates work environment relationships that promote the achievement of organizational goals

2. Maintains work environment relationships to achieve goals

3. Successfully cooperates with others to achieve goals

4. Encourages employees to cooperate

5. Respects and appreciates the contribution of others

6. Recognizes team achievements

7. Estimates benefits of entering into and staying in a particular partnership

8. Quickly and efficiently resolves problem situations

9. Implements efficient negotiation techniques

10. Ensures the information is delivered to all team members quickly and efficiently

11. Takes the responsibility for decisions

12. Actively participates in finding helpful information in problem solving

13. Respects the privacy of others and builds trust in relations with colleagues

14. Supports new and innovative approaches and views

15. Their attitude positively influences the working atmosphere of the team

The candidate received grade 4.5 from their colleagues.

\section{Determining weights}

Using qualitative and quantitative surveys we got the first ranking of candidates which roughly describes the candidates' quality. The obtained grades $O 1, O 2, O 3, O 4$ are not completely accurate. For this reason, using the AHP method we assigned weights to each of these criteria.

The AHP method involves four main steps:

(1) Step 1 involves formulating decision problem in the form of a hierarchy framework. At the highest level is the main research goal. The middle levels present criteria and sub-criteria, whereas the decision alternatives are at the lowest level (Cheng \& $\mathrm{Li}, 2001 \mathrm{a})$. In this paper 
selecting the significant competencies when promoting employees is the main research goal.

(2) Step 2 involves designing a questionnaire and using pairwise comparison scale of decision elements. At this stage decision - makers are requested to make pairwise comparison for each level of the hierarchy and compare options by using a scale pairwise comparison as shown in Table 2 (Cheng \& Li, 2001b).

(3) Step 3 includes calculating the eigenvalues and eigenvectors to estimate the relative weights of components at different levels. According to Saaty (1980c) the argument for the solution methodology is as follows: Input Step 2's pairwise comparisons and produce the relative weights of elements at each level as output (Jeou-Shyan, Hsuan, Chih-Hsing, Lin, \& Chang-Yen, 2011a). The matrix of the pairwise comparisons is described by (Table 8 ).

(4) Step 4 involves, among other things, aggregating the relative weights of various levels. These weights are calculated in Step 3 for the purpose of generating a vector of composite weights serving as a metric for managerial selection based on their competency. We calculated the Consistency Index (CI) and applied the Consistency Ratio (CR) with the aim of checking the solution consistency (Jeou-Shyan, Hsuan, ChihHsing, Lin, \& Chang-Yen, 2011b).

Numerous software packages are available for performing these calculations. For the purposes of this paper we applied results from Teknomo, 2006a.

By applying the given steps, we calculated weights $p 1, p 2, p 3, p 4$, in which $p 1+p 2+p 3+p 4=1$. The obtained formula applies to all 5 candidates. We get accurate grades based on which we perform the accurate ranking of candidates.

We started from the evaluation matrix, where the promotion criteria were pairwise compared. The evaluation matrix determined the importance of four decision-making criteria that correspond to segments of the overall grade (score) (Teknomo, 2006b).

Table 8. Evaluation matrix and priority vector

\begin{tabular}{lcccccc}
\hline Criterion & A & B & C & D & P. Vector & $W$ \\
\hline A & 1.00 & 3.00 & 7.00 & 9.00 & $57.39 \%$ & 0.57 \\
B & 0.33 & 1.00 & 5.00 & 7.00 & $29.13 \%$ & 0.29 \\
C & 0.14 & 0.20 & 1.00 & 3.00 & $9.03 \%$ & 0.09 \\
D & 0.11 & 0.14 & 0.33 & 1.00 & $4.45 \%$ & 0.05 \\
\hline Sum & 1.59 & 4.34 & 13.33 & 20.00 & $100.00 \%$ & 1.00 \\
\hline
\end{tabular}


Whereby $\lambda_{\max }$ equals 4.2692 (max. eigenvalue), consistency index (CI) and consistency ratio (CR):

$$
\begin{aligned}
& \text { C.I. }=\frac{\lambda_{\max }-n}{n-1}=0.0897, \\
& \text { C.R. }=\frac{\text { C.I. }}{R . I .}=9.97<10 \% \text { acceptable }
\end{aligned}
$$

Calculated CR value was less than the predicted value of 0.10 . Therefore, the consistency of the evaluation matrix was within permitted tolerances. In case the consistency ratio was greater than 0.10 , it was necessary to review subjective assessment.

The overall score was calculated using the following formula: $O=p_{1} O_{1}+p_{2} O_{2}+p_{3} O_{3}+p_{4} O_{4}$ in which $p_{1}=0.57, p_{2}=0.29, p_{3}=0.09, p_{4}=0.05$, whereas grades $O_{1}, O_{2}, O_{3}, O_{4}$ were obtained as a result of primary estimation in which $O_{1}=4.0, O_{2}=4.7, O_{3}=3.0, O_{4}=4.5$. Accordingly, $O=0.57 * 4.7+0.29 * 3.0+0.09 * 4.5+0.05 * 4.0=4.154$.

Using these results, the management of a hotel or travel agency could make different decisions about a given worker such as: further engagement (or not), promotion, etc. The same principle could be used for evaluating and subsequent ranking of other employees.

\section{DISCUSSION AND CONCLUSION}

The role of human resources in hotel and tourism industry is reflected in good planning, recognizing and keeping quality personnel. The application of the competency approach integrates all the functions of human resources management - selection, recruitment, performance evaluation, promotion, training, and development, with the aim of better productivity. It is very important that companies make the right decisions regarding staff selection, and to promptly identify their potentials that can be improved. To avoid subjectivity when selecting or evaluating employee performance, many companies use a variety of software packages that make decision making fast and efficient. These decisions are not final but are used as a guideline for the final decision.

This paper proposes a new approach in using the standard criteria for career advancement in tourism and hotel industry, where the final solution is generally applicable. The AHP method was used to determine the career advancement criteria in tourism and hotel industry. Given knowledge, skills and abilities were used to determine the required criteria for ranking candidates. Of the ten criteria, we selected four depending on the decisions that should be made, namely: foreign language skills, professional knowledge, business planning and teamwork. Relevant weights that we assign to certain criteria also play an important role. These weights influence 
the decision-making process. When determining them, the objective indicators that derive from the characteristics of the problems we deal with are also taken into account, in addition to subjective indicators. The results indicate that the most important criterion is professional knowledge $\left(\mathrm{p}_{1}=0.57\right)$, followed by business planning $\left(\mathrm{p}_{2}=0.29\right)$, and subsequently teamwork $\left(\mathrm{p}_{3}=0.09\right)$, and foreign language skills $\left(\mathrm{p}_{4}=0.05\right)$. These results directly influence the quality of the selection process of executive managers, thus facilitating the decision-making process. Depending on the job position the criteria may be defined otherwise. The purpose of the study was to identify key managerial competencies in tourism and hotel industry in Serbia, as well as to rank the managerial competency demands requested in the abovementioned sector. The proposed management competency framework provides an important implication for HR managers.

This study addresses an important, but yet unexplored topic that is to become increasingly significant in the future. Future work should be based on an attempt to automate all steps (from human resources planning, defining competency approach, decision-making theory to making the final decision) that are presented in this paper, as well as to increase the general applicability of this method in different areas of tourism business.

\section{REFERENCES}

Boyatzis, E., Richard. (2008). Competencies in the $21^{\text {st }}$ century. Journal of Management Development, 27(1), 5-12.

Cheng EWL, Li H. (2001). Information priority-setting for better resource allocation using Analytic Hierarchy Process (AHP). Information Management \& Computer Security, 9(2), 61-70.

Chouhan Singh, V., Srivastava, S. (2014). Understanding Competencies and Competency Modeling - A Literature Survey. Journal of Business and Management, 16(1), 4-22.

Horney, N. F. \& Koonce, R. (1995). The Missing Piece in Reengineering. Training \& Development, 49(12), 37-43.

Jeou-Shyan, H., Hsuan, H., Chih-Hsing, L., Lin, L., Chang-Yen, T. (2011). Competency analysis of top managers in the Taiwanese hotel industry. International Journal of Hospitality Management, 30(4), 1044-1054.

Juul, M. (2015). Tourism and The European Union - Recent trends and policy developments, Directorate-General for Parliamentary Research Services, Brussels: European Parliament

Kurtz, R. \& Bartram, D. (2002). Competency and Individual Performance: Modelling the World of Work. In I. T. Roberts, M. Callinan and D. Bartram (Eds), Organizational Effectiveness: The Role of Psychology (str. 225-255). Chichester: John Wiley.

RPA (2012), Study on the impact of EU policies and the measures undertaken in their framework on tourism, Prepared for DG Enterprise and Industry, Final report, Volume 1: Measures, Retrieved from: http://www.ris3balears.org/wpcontent/uploads/2013/06/impact-of-EU-measures-on-tourism.pdf 
Saaty, T. (1980). The Analytic Hierarchy Process. New York: McGraw-Hill International. Spencer, L. \& Spencer, S. (1993). Competence at Work: Model for Superior Performance. John Wiley \& Sons, New York.

Stanković, I., (2013). Edukacija $i$ poverenje na semantickom nivou ( $\mathrm{PhD}$ thesis). [Education and Trust at Semantic Level], Retrieved from https://singipedia. singidunum.ac.rs/izdanje/40984-edukacija-i-poverenje-na-semantickom-webu

Stefanović, V. \& Blagojević, S. (2009). Menadžment ljudskih resursa u turizmu. [Human Resource Management in Tourism]. Novi Sad: Prirodno-matematički fakultet.

Teknomo, K. (2006). Analityc Hierarhy Process (AHP) Tutorial: https://people.revoledu. com/kardi/tutorial/AHP/

Šiber, F. B. (1999). Management ljudskih potencijala. [Human Potential Manangement] Zagreb: Golden marketing.

Vujić, D. (2015). Kompetencije za rad i rukovođenje. [Job Specific Competencies and Management] Beograd: Centar za primenjenu psihologiju

Wood, R. \& Payne, T. (1998). Competency - based Recruitment and Selection. Chichester: John Wiley \& Sons.

\title{
МОДЕЛ КОМПЕТЕНЦИЈА И ВИШЕКРИТЕРИЈУМСКО ОДЛУЧИВАЊЕ У ТУРИЗМУ И ХОТЕЛИЈЕРСТВУ СРБИЈЕ
}

\author{
Наташа Станишић, Слободан Черовић \\ Универзитет Сингидунум, Факултет за туристички и хотелијерски менаџмент, \\ Београд, Србија
}

\section{Резиме}

Развој информационих технологија, појава нових тржишта, потреба за хибридним облицима радних места где запослени ради више послова - указују на потребу за непрестаним процесом учења, обуке и усавршавања. Нагласак се ставља на људе, њихова знања, вештине и способности путем којих хотели и туристичке агенције постају конкурентни на тржишту. Приликом планирања људских ресурса важно је да менаџери, тј. доносиоци одлука, одаберу прави приступ у процесима одабира, регрутације, напредовања, развоја и оцењивања учинка запослених; што ће, са друге стране, довести до смањења флуктуације запослених, трошкова пословања, а квалитет услуге ће се побољшати. Због тога је веома битно одабрати праве софтверске алате и идентификовати кључне компетенције како би се постигла продуктивност и конкурентска предност на тржишту. Модели компетенција су општеприхваћени концепт који интегрише све аспекте управљања људским ресурсима. Њихов значај огледа се у томе да олакшавају опис посла и захтеве према извршиоцу, а са друге стране усклађују перформансе запослених са визијом и мисијом организације (Vujić, 2015, p. 70).

Циљ овог рада био је да се осмисли софтверски пакет који ће на примеру избора извршних менаџера у хотелима и туристичким агенцијама приказати конкретно све кораке примене пословног одлучивања у области људских ресурса. У раду је представљен теоријски оквир знања и компетенција потребних у области туризма. На основу датих знања и компетенција, дефинисани су општи критеријуми за напредовање менаџера. Сваком критеријуму додељиване су тежине које 
су биле у надлежности непосредног руководиоца, односно доносиоца одлуке. Приликом формирања вишекритеријумског модела, било је важно уочити могуће недостатке - у циљу доношења најбоље одлуке.

Иако се метод развијен у овом раду користи за одређивање критеријума за напредовање запослених у туризму, он је општег типа и може се применити и на друге области пословања. 